\title{
Recent Achievements in Land Use Studies in Japan
}

\author{
Yukio HimiYamA* and Kiyotaka Jitsu**
}

\begin{abstract}
Land use studies in Japan in the 1980s have been reviewed and evaluated, their outcomes and related problems discussed, and a new direction for the discipline proposed, based on the achievements of the International Symposium on Land Use Change and Its Processes held at Asahikawa and Sapporo in August 1987 under the auspices of the IGU. The reference articles have been drawn not only from geography, but from several other disciplines, partly because of the interdisciplinary nature of land use studies, and partly because of the lack of coordination of the related disciplines. It has been argued that serious problems exist with regard to the provision and use of national land use data, as well as the excessive regionalism that leads to an ignorance of the national context. It has been proposed to establish an independent and interdisciplinary approach capable of both enhancing the people's understanding of national land use and making sound, fact-based proposals for present and future land use.
\end{abstract}

\section{Introduction}

In a country such as Japan, where land is scarce and population density is high, careful management of land use is a vital necessity. Current land use and land use conversion are the concerns of not only the present but also future generations, and what happens in Japan is no longer a mere domestic matter, as it may have links with land use conversion or sometimes even environmental or socio-economic deterioration in other countries. Decisions on land use should be made with these factors in mind, based on accurate and balanced knowledge of the real situation. Questions then arise as to how much we truly know of the actual situation in land use, the changes it is undergoing and the implications of these changes, and to what degree this knowledge is reflected in decisionmaking. These are the questions that are continually asked throughout the present paper.

Land is considered as space, scape, territory, location, ecosystem, resource and, above all, human habitat. Therefore, it is irrelevant to reckon land use to be a mere economic or political phenomenon, or to regard it as synonymous with planning or subordinate to other academic disciplines. It is studied both in urban and rural contexts, and there is a wide range of disciplines involved, such as geography, urban engineering, planning, agriculture, or economics. Writing on the proposed title has hence involved a search for related works scattered over various disciplines either overlapping or segregated from one another.

Land use should be treated from a truly integrated and human viewpoint, and students of land use should be those who handle the question of the use of land and inland \& coastal waters as something that is essential to present and future human existence and well-being. It is interesting and worth studying in its own right, and hence it is now desirable that it be established as an independent, interdisciplinary subject. The launching in 1984 of a new international journal Land Use Policy, and its growing circulation, may suggest this recent trend of thought (Coleman, 1985b).

It was fortunate that a study group on land use was set up within the Association of Japanese Geographers (AJG), in October 1985, in order to organize land use researchers, and to shed light on a subject which had remained relatively inconspicuous for three decades. The group played a central role in the organization of the IGU's International Symposium on Land Use Change and Its Processes held in August 1987 at Asahikawa and Sapporo. That such a Symposium could in fact be held in Japan with the sponsorship of the AJG indicates that geographers in Japan are now ready to play a decisive role in the coordination, systematization and development of land use studies in

* Hokkaido University of Education, Hokumoncho 9-chome, Asahikawa 070

** Faculty of Education, University of Toyama, Gofuku 3190, Toyama 930 
the country. As many as sixteen papers on various aspects of Japanese land use and land use policies were presented at the meeting, and they practically covered most kinds of current land use issues.

The achievements of the Symposium are closely reflected in the present paper, which reviews and evaluates recent land use studies in Japan, discusses their achievements and the existing problems, and proposes a new direction for the discipline.

\section{Provision and Utilization of National Land Use Data}

Japan is said to be one of the most advanced countries in the world in terms of quality and quantity of land use data. However, it is often mentioned that many kinds of governmental, prefectural and municipal data available as reference material for land use studies remain unused, or nearly so, despite the enormous labour invested in their compilation. Why is this so, and how much and by what means do we know the real situation of national land use?

\section{Land use maps}

Land use is a spatial phenomenon, which cannot be understood fully without being shown in map form. Land use maps are the most basic means of showing land use, and there are many kinds of them on various scales in Japan. The production of good land use maps and their proper use are most fundamental to a sensible land use policy.

The Geographical Survey Institute (GSI) has been solely responsible for all the national land use surveys and the production of national land use maps in Japan. Geographers have undertaken the job of presenting new analytical methods, as well as using the maps produced, for the study of land use and school education. Most of their research, however, utilizes only a very few maps convering very small areas. It is interesting to remember that the First and the Second Land Utilisation Survey of Britain, both of which were directed by academic geographers, did produce land use maps that were used not only for research purposes, but for school education, yielding highly laudable results. The Japanese national land use maps can, and should, be used as thoroughly as in Britain for the enhancement of the understanding of national land use, and for the promotion of geography education.

The GSI started to publish a series of $1: 25,000$ land use maps in 1975. The maps cover most of the country's populated areas and show some forty land use types, both of urban and rural kinds. They were originally intended for use in land use planning, but few planning offices actually venture to use them because, it is said, they are not up-dated and the land use categories and map scales do not meet the requirements of the planners. Y. HimiYama (1985) believed that if the maps were regularly revised and analytical methods presented, they would be used more widely and effectiely. He analyzed over 100 maps and the digital data derived from them, and pointed out the usefulness of the information they supplied. Sample analyses were provided in the paper for seventeen cities, and the land use structures of the urban areas of these cities were quantitatively compared and contrasted. The comparison of city land uses as demonstrated in this paper became possible only after the following conditions were met:

1) Publication of land use maps covering much of the country's populated areas on a scale large enough for the observer to differentiate verious urban land uses.

2) Transference of maps into digital data usable on a computer.

3) Invention of a computer-assisted technique of delineating true (not administrative) urban areas.

The first has been carried out by the GSI, and the remainder by HimiYama.

H. Dor (1987a) attempted to modify Himiyama's method of delineating urban areas and extend it to rural land use. His aim was to produce a kind of 'scape-and-fringe' map, which was first proposed in Britain by A. COLEMAN as a tool to check the relevance of planners' achievements in creating favorable land use patterns (ColEMAN, 1976).

$\mathrm{He}$ applied his method to the $1: 25,000$ land use maps covering Hiroshima City, but this same method needs to be applied and tested at many other places before it can establish itself as a useful and operational technique. 
One of the latest achievements of the GSI is the production of a series of $1: 200,000$ national land use maps, which started to be published in 1984 . T. AKAGIRI of the GSI, the chief architect of this map series, has written about its significance and technical characteristics on several occasions (AkAGIRI, 1985). The new maps are mainly based on the 1:25,000 land use maps and the Digital National Land Information, and include no new information of their own. Because of the recency of their publication, however, their use still remains an issue for future consideration. However, as they fully cover the whole country, it is hoped that they will eventually be utilized in national-scale land use studies.

\section{The digital national land information}

Land-use data in the Digital National Land Information (DNLI) were compiled in 1976 by the GSI. The information system includes a wide range of information for each of several types of unit area, such as a grid square or municipality, and is provided on magnetic tapes usable on a computer. It covers the whole country, and is useful for national-scale researches on land use, though such researches have hitherto been rather rare. Most of the studies based on this information system take advantage of another of its characteristics, i.e., the fact that it includes many environmental categories as well as land use within the same data framework.

Soon after the compilation of the DNLI, the GSI initiated the analysis of the data. The interrelationships between land form and land use have comprised the most common and successful topic among such works. R. SETo's 'Utilization of Data Bank on Grid Square Basis for Regional Planning' (1980) is one such work. It is based on the analysis of the DNLI and the Statistics on Grid Square Basis. These data together include a wide range of land information and socioeconomic statistics which, she asserts, are useful for land development/conservation planning and regional planning. In order to demonstrate to planners the use of these data, she selected the Tokyo metropolitan area and produced computer maps showing such items as 'land use type by landform classification', or 'selection of suitable areas for sightseeing and recreation'. SETo (1986) advanced further to show quantitatively the loca- tional correspondence between types of land use and landform, and the regional variations trereof. Although discussions on land use vs. the landform issue itself are not particularly new, the fact that this work dealt with the entire country is notable.

Biтo (1987) also used the DNLI for an examination of the inter-relationships between land use and various land conditions such as landform, altitude, relief, or slope angle, at Tama Hill area in the suburbs of Tokyo. His major interest appears to be the establishment of a method of introducing the DNLI into a more traditional geographical study of rapidly expanding suburban residential areas. It may be argued that the use of the DNLI in the above study is irrelevant because more precise and up-to-date local data are obtainable. This may be partly true, but the advantages of the DNLI, such its nation-wide coverage, the great number of variables included, or its easy comparability to other governmental data on grid-square basis, should not be undervalued. There are still many ways of using the DNLI before discarding it for its shortcomings.

\section{The survey of land use trend}

Every prefecture in Japan carries out an annual survey called the 'Survey of Land Use Trends', and publishes a report which has the same name as the Survey itself. The Survey report consists of four items, i.e., two booklets of statistical tables and two maps corresponding to them, respectively. In the circumstances, where no national land use map series has been renewed to date, the Survey is probably the most comprehensive and detailed information source of the national, as well as prefectural, land use trends in the 1980s. Prefectural reports started to be published in 1980 , but the contents were not carefully checked nor properly utilized until recently, at least at the national level. It is regrettable that such a potentially useful information source has largely been ignored not only by academics, but by governmental or prefectural planners, who are supposed to utilize it in the management of the Land Use Master Plan.

When Y. Нiмтуама took the initiative of checking and compiling the statistical data in the reports, they were hardly usable because there were too many and serious errors. In 'Land Transactions and Land Developments in Japan 1980-1985: A 
Summary of the Survey of Land Use Trend' (Himiyama 1987a), he traced some aspects of the land use trends in Japan in the 1980s. HimiYama (1987b) went on further to analyze the data on land transactions which form part of the Survey, and showed quantitatively the nationwide trends of land transactions for various purposes, by prefecture. The transaction data are based on the National Land Use Planning Act, and are known to be good indicators of land use changes. The Survey should attract greater attention on the part of students of land use, and contribute to a better understanding of land use trends. It is hoped that the Survey will be continued with improvements as it goes along, but excluding the destructive modifications that governmental data sometimes undergo.

\section{Landsat imagery data}

Landsat imagery is no longer a specialist's tool. It can be seen in non-professional books, or even on the walls of ordinary offices. When shown on a small scale, it looks nearly the same as a land use map, as it differentiates forests, some kinds of farmlands, towns, or deserts. Its use in a macroscale survey of land cover is already wellestablished technically, if not academically. It is therefore no surprise if people think that Landsat will in future take over field surveys. However, what Landsat imagery actually shows is land cover rather than land use, and there is a growing awareness that it only offers far poorer resolution than previously expected, leaving many individual land uses unrevealed. There has been a great deal of research since the 1970s focusing on the microscale usage of Landsat data, but few works of geographical significance have emerged to date.

The most realistic and hopeful use of Landsat imagery data for a detailed-scale study is said to be the monitoring of paddy field conversion, which requires a periodic field survey. T. SAтоH (1985) used the Lansat MSS data in his survey of paddy field conversion, considering the advantages of the Landsat MSS data as follows:

1) They cover a large ground surface at very short time intervals.

2) Data are renewable fairly frequently, say every year.

3) Data are easy to process on a computer, and can be easily overlaid, say, the DNLI.

SAтон further developed his technique, and insisted, though arguably, that he could differentiate paddy fields clearly, and that the data could be used for a detailed-scale study (SАтон, 1986, 1987). 'Comparative Analysis between Land Cover Pattern from Landsat Data and Land Productivity pattern from Digital National Land Information' (SAZANAmi et al., 1986) is an another pilot study of a similar kind.

The resolution level will no doubt improve in future, but the use of the Landsat MSS data for micro-scale land use study still seems to be far from practicable. It is not yet certain how far and how quickly the improvement of the analytical method and related hardware will be accomplished.

\section{Studies on Urban and Peri-urban Land Use}

Urban areas have been expanding rapidly, accompanied by drastic land use and environmental changes in both urban and peri-urban areas. Forceful urbanization has also been the major cause of the tremendous changes in the rural human landscape. The extreme shortage of residential land and skyrocketing land prices in metropolitan areas have convinced many people of the urgency of land problems, though these are often too narrowly focused on land prices, disregarding many other important aspects of the problems. There are various urban problems, including land problems, and many of them are related with land use in one way or another. It is to be hoped that studies on urban and peri-urban land use will serve to contribute to the maintenance and creation of good urban and peri-urban environment by providing necessary information on and factbased ideas regarding the city and surrounding land use.

\section{Grasping urban and peri-urban land use and its changes}

That urban areas are expanding is obvious to all. That urban land use structure is changing is also apparent. The problem is how accurate and comprehensive our knowledge of these aspects is.

Japanese cities are supposed to produce largescale land use maps of their administrative terri- 
tories every five years or so. Although they often go unpublished, they comprise a potentially useful tool for the purpose of learning about municipal land use and the changes it is undergoing. The maps of different cities are not readily comparable because of the difference of land use categories or map scales but, unlike the GSI land use maps, they are renewed regularly, so that land use changes are identifiable on them. H. Dor (1984) measured land use changes in part of the suburbs of Matsuyama City on the large-scale land use maps of the years 1971 and 1976 provided by the city authorities. T. IsHIMARU (1986) also used similar large-scale land use maps of the year 1980 provided by Hiroshima City, and analyzed the land use patterns. It is now required to utilize these municipal land use maps in carrying out comparative studies of land use and its changes in various cities.

'Detailed Digital Land Use Data' (Takuchi-dokochosa) of the three major metropolitan areas, i.e., Keihin, Hanshin and Nagoya, have been provided by the GSI. The data have been derived from aerial photographs and compiled in digital form for each of $10 \times 10 \mathrm{~m}^{2}$ areal units. K. OTAKE $e t$ al. (1985) and N. NAGAI et al. (1987) discussed their use and significance for urban land use studies. The data are available for 1974 and 1979 , so that they can be used to show land use changes during the latter half of the 1970s. As they are supplied in digital form and are usable on a computer, they are particularly effective in identifying land use conversions and their areal extensions. The scope of the use of these data largely depends on how frequently and regularly they are renewed.

Multiple use of the same land area is an important aspect of urban land use. There are various kinds of situations, but those where different activities take place at different levels above or below the ground have been the major focus of research. A detailed land use study of a densely built up area inevitably encounters this issue. From the standpoint of land use study, it is necessary to know more about the uses and characteristics of multi-story buildings and the surrounding environment. This is the academic domain where geography meets with architecture or psychology, and a number of well-established contributions by geographers in the West (e.g., Coleman, 1985a) exist. T. TорокоRо's 'Vertical Use of Urban Space'
(1986) constitutes a timely summary of related researches on the subject known up to that date. Other articles along the same lines include $\mathrm{K}$. Kuwajima (1984) and M. Yamashita (1985). In spite of these works and many other works of similar kinds, studies on multi-level land uses are still somewhat isolated in the geographic world which is as yet dominated by two-dimensional facts and thoughts.

There have also been various other kinds of urban and peri-urban studies to note: K. TANAKA (1982) and M. OHE (1986) analyzed the effects of land ownership on land use in the suburbs and centre of Tokyo, respectively; J. KitabataKe (1981) and M. SAito (1987) dealt with housing development in hilly suburban areas; S. Kuво (1983) studied the processes of land use change vs. environmental condition in the hilly suburbs of Hachioji City, Tokyo. The paper is noted for its contribution towards the use of computer-graphic techniques for land use studies; T. InUI (1982), M. YoKOHARI (1986) and N. HASHIZUME (1987) discussed the roles and preservation of urban woodlands.

R.D. HILL, the chairman of the IGU Working Group on the Dynamics of Land Use Systems, proposed in the group's bulletin of 1986 the launching of an international project titled 'The Spatial Dimension of Urban Growth 1950-1980'. Rapid spatial expansion of cities has been a worldwide phenomenon since the Second World War, and people regard it as a matter of fact. However, the fact is that very little is accurately known about this phenomenon and its effects. Rapid urbanization is one of the greatest international problems the world now faces, and a precise and comprehensive knowledge of these problems is an urgent necessity. A report on the expansion of Japanese cities should be produced without delay, and it should include maps that show the rate and extent of city expansion, as well as statistical figures and statements.

\section{Land use control and planning}

A major element of the new City Planning Act, which was amended in 1968, was the introduction of a measure called sen-biki, or differentiation of Urbanization Promotion Zones (UPZ) and Urbanization Control Zones (UCZ) within City Planning Areas (CPA). The purpose of this zoning is to 
prevent 'disorderly' urban sprawl and to keep both urban and surrounding rural areas in good condition. The examination of the effectiveness of the measure already started in the 1970s, and continued into the 1980s, though the definition and the relevance of 'orderliness' have not been fully elaborated.

M. Urayama et al. (1981) selected the OwariSeibu region, where a rapid urban sprawl within the UCZ resulted in a chaotic land-use mixture, deterioration of the agricultural environment, and increased danger of flooding, and discussed the reasons for the region's having become a potential disaster area. Their major finding was that the UPZ of the selected region was too small to meet the land demand there, and this factor accelerated urban sprawl into the UCZ. T. KIDOKORO et al.(1982) observed the case of Takasaki City, and reached the opposite conclusion, that is, that the too large UPZ accelerated unfavourable urban sprawl. T. IKEDA (1986) studied the case of scattered settlements within a UCZ in Okinawa, and discussed how the sen-biki measure should be modified. Y. Ohsakaya and H. Yokoyama (1983), both in the Building Research Institute of the Ministry of Construction, surveyed land use changes and population trends in the two types of land use zone, i.e., the UPZ and the UCZ, in virtually all CPAs of the country, and examined the effectiveness of the measure as a sprawl regulator. They concluded that the measure was effective on the grounds that there was only a minor social increase of population within the UCZs. They also noted that population targets tended to be set unrealistically high, resulting in overly large UPZs in many cities. H. Dor (1987b) compared the urbanizations of three contrasting cities, and found great differences in the actual methods of executing sen-biki, and their varied effects on urbanization.

The above works indicate that we now need to know where and for what reasons the measure went well, or wrong, in order to ensure that it be more appropriate for application in every part of the country. Obviously, this cannot be done by simply observing a few cities, or merely processing statistical figures.

Urban areas are divided into several land use zones called yoto-chiiki, by the City Planning Act. The aim of the measure is said to be the preven- tion of a 'disorderly' mixture of different kinds of land use, while the definition and relevance of 'orderliness' remain, as in the case of the sen-biki, unclear. The major concern of municipal planners has been the rationality and effects of their delineation of land use zones. M. NAKAJO et al. (1983) examined the effect of the zoning in Kobe City by using real estate tax files, and demonstrated its effectiveness as a measure for the purification of the functions of different types of area. The research by K. Yокоун et al. (1984) on Fukuoka City reached the same conclusion, though these researchers employed a different approach. What remains to be done now is the examination of the necessity of the zoning itself as a measure to achieve a favourable land use pattern.

Land readjustment is the most frequently used means of urban development in Japan. K. YAmAZAKI (1981) reported on the effects of a land readjustment project, such as the changes of land ownership and land use, deterioration of the environment, and elimination of agriculture, in the suburbs of Tokyo. M. Honjo \& T. Inoue (1982) offered a good collection of literature provided from the planning side on various aspects of land readjustment in Japan. Land readjustment can be done in various ways. It is not always successful in terms of city-planning, as it may cause local conflicts or accelerate urban sprawl. More works are required in order to examine negative, as well as positive, aspects of the measure.

In 'The Land Problem in the Developed Economy', A. DAwson (1984a) examined land use regulation in Japan as well as in Britain, U.S.A., and Eastern Europe. What struck him most regarding the Japanese control system was the discrepancy between the orderly, hierachical structure of the system and the actual execution of the control measures. In 'Land Use Policy and Control in Japan', DAwson (1984b) outlined the reasons for the introduction of the new Japanese land use control system, described the most important points of the measures, reviewed their effects in the period up to the early 1980 s, and indicated reasons for their failure to bring the allocation of land into line with the National Land Use Plan. R. Azuma (1987) also compared land use control measures in Japan and those in some European countries, and outlined major problems of Japanese legal system, 
such as the duality of the zoning system which resulted from the sectionalism of two governmental departments, incomprehensive areal coverage of the control zones, or shortage of land supply for urban use. As a result, he concluded, the control system was unable to prevent urban sprawl effectively.

J. Chitose (1987), a geographer-planner of the Tokyo Metropolitan Government, reviewed studies in the field of city planning, and commented on them as follows:

1) There has been little progress in theoretical aspects.

2) The study areas were single cities in most cases, and broader comparative studies are rare.

3) The length of the periods covered by the data were often too short for the proposed topics.

4) Most of the works lacked sufficient references to related research.

He also proposed the provision of more land use data, and to study land use as an integrated regional phenomenon.

\section{Locational study of urban land use}

Types of land use and land use changes in urban areas are strongly conditioned by geographic and socio-economic conditions, as well as land price. However, many locational studies in the 1970s and 1980s have narrowly focused on land price and rent, as exemplified by K. Jitsu (1987). More broadly focused articles include that of M. Kondo et al. (1981), which dealt with the inter-relationships between land use types and various locational factors, such as those related with human activities or establishments, in Osaka City. H. NaKahara and M. Ohta (1983) divided the UPZ of Sapporo City into 1205 grid squares, and analyzed the effects of various factors, such as population or access to the city centre, on land price, which in turn conditions land use. They presented a formula for expected land prices, and used it for the prediction of future land use patterns. Their predicted land use based on the 1973 data was compared with the 1978 land use data, and was, according to them, proved to be reasonable.

\section{Studies on Rural Land Use}

According to FAO statistics, the rate of shrinking of farmland in Japan is the highest among developed countries. The remaining farmland is suffering from various interventions, such as fragmentation by new roads or urban sprawl, or the gen-tan, i.e., quota of rice production. The rural scene of Japan has thus been undergoing drastic changes which few foreign countries can match. In view of this uneasy situation, the number of articles on rural land use has been regrettably insufficient in recent years. As for geography, excessive attention has been paid to urban, rather than rural, matters, and many 'rural' studies have actually been carried out from the urban side and are motivated by urban interests. Even more regrettably, land use has been given only a minor status in agricultural geography for some years. Some of the major reasons for this are reckoned as follows:

1) The fact that socio-economic changes in rural communities have been considered more urgent a topic than that of land use changes.

2) Ignorance of the significance and methodology of environmental and landscape studies.

3) Excessive dependence of scholars on official data, which seldom show precise details of land use and its changes.

In any case, it now seems very important to recall the implication of the fact that agriculture does rely on the land, which is limited and requires a careful management.

\section{Grasping rural land use and its change}

In a rural land use study, as well as in other geographical studies, choice of study area is important. Unfortunately, not a few articles deal with a small area as an 'example' or 'representative' of a certain type of region without providing evidence showing that this is actually the case. They fail to specify the context in which the study area has been selected, though many of them claim that they have done so. That is how so many 'case studies' have been accumulated without having been assembled with the purpose of providing more integrated knowledge regarding 
the national land. This tendency towards regionalism, evident in rural studies, is well reflected in the rather reserved and localized use of the Agricultural Census Data.

'The Rural Space of Japan' (Yамамото, et al., eds., 1987) represents a recent attempt to put local studies on rural geography into an integrated national context. The book includes maps of rural spaces classified from the socio-economic and farm-management viewpoint, and discusses the significance of each type of category in each region. The book deals with all of Japan, but its contents are largely based on the authors' field experiences and local knowledge, rather than national statistics or maps. The rationale involved in such a total rejection of national information is disputable but, nevertheless, the book may be regarded as a notable contribution towards a better understanding of the rural scene of Japan including land use. Land use aspects could, however, have been further elaborated.

FujIta and Tomoкuni (1982) studied the land management and land use on the part of the 'urban farmers' and portrayed the processes involved in the conversion of farmland to urban use. Their research involved the observation of individual farm households, as well as a detailed land use survey. They selected their study area because of its very high farmland conversion rate within the Kinki Region. It is hoped that their work is extended to further substantial areas. H. TANo (1986) analyzed the effect of a landimprovement project on changes in land use in the 'island-like upland fields' near Lake Kasumigaura.

Some Japanese geographers have also studied agricultural land use in other countries. Pertinent among their works are 'The Land Use of County Durham in Britain: On its Quantitative Analysis' (Himiyama, 1982), 'The Changes of Agricultural Land Use in the Village of Zehnhausen, the Hoher Westerwald in West Germany' (SakURAI, 1985), 'Soil Erosion and Systems of Cultivation in Middle and South China, Especially Related to Maize Cultivation' (CHIBA, 1986), 'Zonal Patterns of Agricultural Land Use in the State of Paraiba, Northeast Brazil' (SAITO and YAGASAKI, 1987), and 'Regional Changes of Agricultural Land Use in Canada' (ImAI, 1987). The overseas research experiences ought to be reflected in the progress of domestic land use studies.

\section{Land use in marginal land}

Some of more active rural land-use studies in recent years have been those on marginal land. $R$. КімAтA (1982) surveyed land use involving a hilly landcreep region where agriculture is extensively practised with careful adjustments to micro environmental conditions. M. Yамамото (1986) presented a detailed description of agricultural land use involving a remote village in the Kitakami Mountains. G. HAYAFUnE (1987) dealt with the soil erosion problem in marginal farmlands, especially where land form was artificially modified, or where the use of new farming techniques and heavy machinery caused farmland deterioration. He compared such areas with some mountain villages where traditional farming techniques have served the conservation of the soil on steep hillside farmlands. 'Vertical Zonation of Agricultural Land Use on the Lower Southern Slopes of Mt. Asama' (Maruyama, 1987) is based on the author's land use survey maps, and discusses the effect of altitude and other environmental conditions on land use. 'Problems of Resource Degradation in the Depopulated Area: A Case Study of Hibara-mura, Tokyo-to' (OISHI, 1987) is a comprehensive regional report on a village where land use, as well as population, landscape and livelihood, is undergoing rapid change. His concern has been how to protect village life and the environment in the midst of socio-economic turbulence. Y. FuJITA (1987) outlined the changes in mountain land use, both the agricultural and forest kind, in the whole country since the $1950 \mathrm{~s}$. He discussed the existing problems, such as aging and the economic hardships of the remaining population, resort development, and the regional connection of mountain villages with remote cities.

The use of hillsides will become an increasingly important rural, as well as urban, land use issue in Japan because of the scarcity of flat land. It is therefore important to know where and how people can practise hillside farming or other activities without bringing about soil erosion or other unfavourable consequences.

\section{Resort development}

Development of tourist resorts is now widespread throughout Japan, and is becoming an increasingly pressing land use issue, because of its 
wide extension, conflict with other land uses, possible destructive effects on the natural environment, or economic effects on village life. There have been relatively few scholars who deal with resort or tourism in Japan from the land use viewpoint, but the number is on the increase. In 'The Formation of Resort-Type Tourist Areas along Coastal Regions: The example of Hazako Settlement in Hamajima-cho, Mie Prefecture', A. Tanno (1986) described an example of the development of a coastal resort in a once poor remote village, and discussed some aspects of the land use changes involved. 'Changing Process of Land of Common Lands by the Development of Tateshina Resort Zone, Nagano Prefecture' (Ike, 1986) showed how former 'common lands' were turned to resort areas and contributed to the local economy.

Unlike Occidental countries, there have been few academic works on resort development in Japan. Resorts are not limited to scenic places, but are now found even at would-be industrial sites. As industrialization is on the wane, resort development is becoming a major economic and political attraction in many parts of the country. It is likely to be a major land use issue during the coming decade, and intensive academic approaches will be required, in order not to make the coming decade an age of environmental destruction. It is important to understand its meaning in the context of long-term national land use.

\section{Environmental Land Use Planning}

There still prevails a belief that human beings are, or will in future be, able to modify land forms in order to establish any kind of land use wherever they like, with the aid of powerful earth-moving machines. Hence, the development of farmland is progressing in deforested mountain areas, bay waters are filled in to form new lands, and roads are constructed even in deep mountain regions that are often ecologically fragile and sensitive. It is regrettable that a too strong criticism of environmental determinism has resulted in the obstruction of studies on man-environment interactions in the field of geography, while environmental conservation being such a great social concern. Geographers should maintain closer academic ties with other disciplines, to make a fair contribution to discussions on man-environ- ment issues.

Y. Shimazu (1985) states that future land use should be regulated so that it dose not damage existing favourable environments, and that environmental assessment should be carried out at the time of the earliest stage of development planning. At present, he says, it is done only after locational selections and other important decisions have been made.

H. ShapiRo (1987), an American regional planner who works in Japan, stresses the importance of ecologically favourable land use planning at coastal areas that include not only land but coastal waters. His ecological inventory includes geology, surface hydrology, climate, soils, flora and fauna, and current land and water use. Based on this inventory, he proposes the following criteria for coastal urban environmental planning: safety (earthquake/tsunami hazard potential, maritime explosion/fire hazard potential); amenity (aesthetic/scenic values); (natural health/welfare: aquifer recharge areas, potential biological productivity). He criticizes development plans, such as the 'Tokyo Bay Cosmopolis Plan', that call for the covering of much of the Bay's surface for industrial and urban use, on the grounds that they ignore the problems of land subsidence and seismicity as well as the implications for even further population concentration in the Capital Region. He says that instead of merely dwelling on past or present projects in the Bay area, an attempt should be made to adopt a broad, future-oriented view based on the integrated ecological approach established in his study. Moreover, it is desirable that the above approach be further extended to include inland regions which pose similar land use problems.

Another recent manifestation of environmental concern is the proposal of a 'Nature-Oriented Land Use Planning', i.e., a planning of land use that allows people to make the most effective and durable use of land without disturbing natural diversity or damaging the environment (IDE and TAKEUCHI, 1985). The authors criticize recent forms of land use that ignore local environmental conditions, and propose ways to establish environmentally justifiable land use planning.

The involvement of the Environment Agency in land use is now evident, though still in a reserved way, as represented by its inclusion of a chapter 
on land use in its 1987 White Paper (Environment Agency, 1987). The Agency first launched a project for an 'Environment Use Guide' in 1984. The Guide was produced for the use of particular regions of environmental or other importance, by the prefectural authorities concerned, under the sponsorship of the Environment Agency (e.g., Hokkaido Prefectural Government, 1985). It includes various grid maps showing landform, geology, soil, vegetation, water quality and many other items. Although the maps are basic, they nevertheless show what should be taken into account for the preservation or use of the designated regions.

\section{Concluding Remarks}

The bulk of the research themes of the 1980s have revealed a progressive continuation of the themes of the 1970s. The present decade has also evidence some notable new trends in awareness, e.g., a growing concern with environmental deterioration and a widening recognition of the necessity of overall national land use studies. However, no little research focusing on very small areas has been found to be overlooked, not having been justly evaluated in the context of national land use. There have also been serious problems with the provision and the use of national land use data. It has been argued that studies on land use in the 1980s are insufficient in many respects, and that we actually know very little about the land use and related problems of our rapidly changing country.

In view of the limited land area and scarcity of natural resources, the affluence of Japan over the last twenty years might after all have been a matter of good luck, as much as a result of the ingenuity of the people. However, this period seems to have left us with many and serious land use problems which should be tackled without delay. The necessity of land use studies may be best understood at times of economic, social or environmental hardships. The problem is that by the time the majority of the people become aware of the mismanagement of the land, it may be simply too late for countermeasures to be effective.

In Britain, the 1980s have been designated as the 'Land Decade', in order to instigate the promotion of land use research and education. It is proposed here to make the 1990s the 'land decade' of Japan. It is now necessary to establish an independent and interdisciplinary area of study capable of enhancing people's understanding of national land use and initiating sound proposals, formed on the basis of fact, pertaining to present and future land use.

(Received November 25, 1987) (Accepted February 15, 1988)

\section{References}

AKAGIRI, T. (1985): On the Land Use Map Series on a Scale of 1 to 200,000. Journal of Geography, 94, 58-64. (J)

AzumA, R. (1987): Public Intervention in Land Use Conversion: Western Europe and Japan, symposium paper.

Biтo, A. (1987): Land Condition and Land Use in the Tama Hill Area: Research Using Digital National Land Information, symposium paper.

CHIBA, T. (1986): Soil Erosion and Systems of Cultivation in Middle and South China, Especially Related to Maize Cultivation. Geographical Review of Japan (Ser. B), 59, 21-30.

Chitose, T. (1987): On Urban Land Use Studies in the Field of City Planning in Japan. Geographical Review of Japan (Ser. A), 60, 20-39. (J-E)

ColemAn, A. (1976): Land Use Planning: Success or Failure ?. Architects' Journal, 165, 91-134.

Coleman, A. (1985a): Utopia on Trial. Hilary Shipman, $219 \mathrm{p}$.

Coleman, A. (1985b): Land Use Studies in Britain. Annals of the Tohoku Geographical Association, 37, 306-312.

Dawson, A.H. (1984a): The land Problem in the Developed Economy. Croom Helm, $265 \mathrm{p}$.

Dawson, A.H. (1984b): Land Use Policy and Control in Japan. Land Use Policy, 2(1), 54-60.

Environment Agency (1987): Kankyo hakusho (White Paper on Environment), Env. Agency, 542 p. (J)

DoI, H. (1984): Land-Use Changes in the RuralUrban Fringe: a case study of Matsuyama City. The Human Geography, 36, 1-21. (J-E)

DoI, H. (1987a): A Making of the Scape and Fringe Map by Use of Japanese Land-Use Map. Geographical Review of Japan (Ser. A), 60, 265-277. (J-E)

DoI, H. (1987b): Land Use Control in the PeriUrban Areas in Japan, symposium paper.

FujiTA, Y. and T. TомокUNI (1982): Land Management and Land Use of Urban Farmers in Toyonaka City, Osaka Prefecture. Proceedings of the Faculty of Literature, Univ. of Aichi, 70, 1-35. (J)

FujITA, Y. (1987): The Changes in Mountain Land Use Since the Period of Higher Economic Growth in Japan, symposium paper.

HASHIzume, N. (1987): A New Trend of the Greenery 
Conservation Projects by the Municipal Governments in Chiba Prefecture. Geographical Review of Japan (Ser. A), 60, 170-180. (J-E)

HAYAFunE, G. (1987): Land Use Cchanges and Farmland Conservation at the Foot of Mt. Tokachi and the Upper Tama Valley, symposium paper.

HimiYama, Y. (1982): The Land Use of County Durham in Britain: on its Quantitative Analysis. Annals of the Hokkaido Geographical Society, 56, 33-39. (J)

HimiYama, Y. (1985): The Use of Japanese Land Use Maps at $1: 25,000$. Land Use Policy, 2, 278-288.

HIMIYAMA, Y. (1987a): Land Transactions and Land Developments in Japan 1980-1985: a Summary of the Survey of Land Use Trends. Hokkaido Univ. of Education at Asahikawa Geog. Reports, 5, $94 \mathrm{p}$.

HimiYama, Y. (1987b): Recent Trends in Land Transactions in Japan, symposium paper.

Hokkaido Prefectural Government (1985): Minami Ishikari Chiiki Kankyo Riyo Gaido (Environmental Use Guide of Southern Ishikari Region), Hokkaido Pref. Gov., 125 p. (J)

Honjo, M. and T. Inoue (eds.) (1982): Urban Development Policies and Land Management: Japan and Asia. City of Nagoya, $389 \mathrm{p}$.

IDE, H. and K. TAKEUCHI (1985): Shizen ritchi-teki tochi riyo (Nature-oriented Land Use Planning). Tokyo Univ. Press, 227 p. (J)

IKE, S. (1986): Changing Process of Land Use of Common Lands by the Development of Tateshina Resort Zone, Nagano Prefecture. Geographical Review of Japan (Ser. A), 59, 131-153. (J-E)

IKEDA, T. (1986): The Limit and Improvement of Senbiki System for the Control of Dispersive Urbanization: throughout the Actual Condition of the Urbanization Control Area in Shimajiri of Okinawa Southern Part. Toshikeikaku Supplement, 21, 337-342. (J-E)

IMAI, T. (1987): Regional Changes of Agricultural Land Use in Canada. Annals of the Hokkaido Geographical Society, 61, 9-17. (J-E)

INUI, T. (1982): On the Significant Utilization of the Flatland Forests in Agriculture in the Western Suburbs of Tokyo. Geographical Review of Japan, 55, 549-565. (J-E)

IsHIMARU, T. (1986): Land Use Patterns in the Former Built-up Area of Hiroshima City. Geog. Sciences, 41, 25-37. (J-E)

JiTSU, K. (1987): Dynamics of Urban Land Use in Terms of Land Prices: Comparative Analysis of Major Cities in U.S.A., Europe and Japan. Geog. Reports of Tokyo Metropolitan Univ., 22, 41-48. (J-E)

KiDOKORO, T., K. OHMURA and M. OHTA (1982): A Study on the Characteristics of the Area in Takasaki City Urbanized during the 1960s and 1970s. Toshikeikaku Supplement, 17, 1-6. (J-E)

KIMATA, R. (1982): Land Use Type of Slopes in Landcreep Zones in Mineoka Range, the Boso Peninsula, Central Japan. Annals of the Tohoku Geographical Association, 34, 108-117. (J-E).

KitabataKe, J. (1981): Housing Development in the
Northwestern Hilly Part of the Nara Basin. Geographical Review of Japan, 54, 437-447. (J-E)

Kondo, M., M. AmANo and H. ABE (1981): Urban Land Use and Its Change. Toshikeikaku Supplement, 16, 223-228. (J)

Kubo, S. (1983): Changing Process of Land Use and Evaluating Its Mixture. Bulletin of the Dept. of Geog., Univ. of Tokyo, 15, 93-124.

KuwAJIMA, K. (1984): Vertical Growth of CBD of Sendai and Fukushima: through the Volume Size and Floor Use of Multi-storied Buildings (over three stories). Annals of the Tohoku Geographical Association, 36, 119-130. (J-E)

MaruYAmA, H. (1987): Vertical Zonation of Agricultural Land Use on the Lower Southern Slopes of Mt. Asama. Geographical Review of Japan (Ser. A), 60 , 643-666. (J-E)

Nagai, N., T. HoYa, A. Yaguchi and T. Akagiri (1987): Detailed Digital Land Use Survey in the Metropolitan Regions in Japan, symposium paper.

NAKAHARA, H. and M. OHTA (1983): A Study on the Change in Urban Land Use through Analysis on Land Value. Toshikeikaku Supplement 18, 214-246. (J-E)

NAKAJO, M., T. EDAMURA and N. SAKAI (1983): Examination of the Effect of Zoning Regulation on Urban Land Use: the Analysis on City of Kobe. Toshikeikaku Supplement, 18, 235-240. (J-E)

OHE, M. (1986): The Changes of Land Use, Landownerships and Residents in the C.B.D. of Tokyo. Toshike $i$ kaku Supplement, 21, 277-282. (J-E)

Ohsakaya, Y. and H. Yokoyama (1983): A Study on the Characteristics of Urbanization under UPA and UCA. Toshikeikaku Supplement, 18, 271-276. (J-E)

Orshi, T. (1987): Land Resource Degradation in the Depopulated Marginal Regions. In Tokyo Pref. Office, (ed.): Hibara-mura ni okeru kaso mondai ni tsuite (Depopulation of Hibara-mura). 147-235. (J)

OTAKE, K., E. TSURUMI and N. INOUE (1985): Collection of Detailed Digital Land Use Data and Its Use. Bulletin of GSI, 29, 65-74.

SAITO, I. and N. YAGASAKI (1987): Zonal Patterns of Agricultural Land Use in the State of Paraiba, Northeast Brazil. Geographical Review of Japan (Ser. B), 60, 66-82. (J-E)

SAITO, M. (1987): Development of Housing Estates (Danchi) in Hilly Areas in Kobe, symposium paper.

SAKURAI, A. (1985): The Changes of Agricultural Land Use in the Village of Zehnhausen, the Hoher Westerwald in West Germany. The Human Geography, 37, 26-51. (J-E)

SATOH, T. (1985): Agricultural Land Use Survey by Satellite Remote Sensing. Journal of Geography, 94, 27-38. (J-E)

SAToh, T. (1986): Paddy Field Classification by Remote Sensing. The Proceedings of the Department of Humanities, College of Arts and Sciences, University of Tokyo, 84, 1-9. (J-E)

SATOH, T. (1987): Agricultural Land Use Survey by Landsat MSS Data, symposium paper. 
SazANami, K., K. Isobe, Y. Nakayama and T. Yamamoto (1986): Comparative Analysis between Land Cover Pattern from Landsat Data and Land Productivity Pattern from Digital National Land Information. Journal of the Remote Sensing Society of Japan, 6, 93-104. (J-E)

SETO, R. (1980): Utilization of Data Bank on Grid Square Basis for Regional Planning. Geojounal, 4, 319-332.

SETO, R. (1986): Land Use by Landform Classification in Japan: analysis with the Data of Grid Square Basis. Map, Journal of the Japan Cartographers Association, 24(4), 1-11. (J-E)

SHAPIRO, H. (1987): Toward an Ecological Basis for Land Use Planning Japanese Coastal Cities: A Tokyo Bay Example, symposium paper

SHIMAZU, Y. (1985): Proceedings of the Land Use Workshop, unpublished conference report on regional environmental planning.

TANAKA, K. (1982): Changes in Landownership and Land Use of Former Farmers in Nakano-ku and Musashinoshi, Tokyo. Geographical Review of Japan, 55, 453-471. (J-E)

Tanno, A. (1986): The Formation of Resourt-Type Tourist Areas along Coastal Regions: the Example of Hazako settlement in Hamajima-cho, Mie Prefecture. The Human Geography, 38, 7-25. (J-E)

TANO, H. (1986): Land Improvements and Changes in Land Utilization for the Shimabatake (Island-Like Upland Field) of the South Coast of Lake Kasumigaura. Proceedings of the Inst. of Natural Sciences, Nihon Univ., 21, 33-44. (J-E)

TADOKORO, T. (1986): Toshi kukan no rittaika (Vertical Use of Urban Space). Kokon-shoin, 244 p. (J)

Urayama, M., K. SATOH, K. AOYAMA and T. IzAWA (1981):
Sprawl in the Urbanization Control Zone and Land Use Planning. Toshikeikaku Supplement, 16, 199-204. (J)

YAмамото, M. (1986): Development of Diversified Farming with Livestock and Transformation of Land Utilization in the Northern Kitakami Mountains. Geographical Review of Japan (Ser. A), 59, 706-728. (J-E)

YAMAMOTO, S., Y. KITABAYASHI and A. TABAYASHI (1987): Nihon no noson kukan (The Rural Space of Japan). Kokon Shoin, 423 p. (J)

YAMASHITA, M. (1985): Land Use in Matsumoto's CBD from a Three-dimensional Point of View. Area Research Paper, 7, Inst. of Geo-Science, Univ. of Tsukuba, 79-89. (J)

YAMAZAKI, K. (1981): Changes in Land Tenure and Agricultural and Environmental Problems in Land Readjustment Projects: a Case Study of the Horie Land Readjustment Projects in Edogawa-ku, Tokyo. Geographical Review of Japan, 54, 231-246.

YOKOHARI, M. (1986): Fundamental Study on Decreasing Process of Coppice in Urban Fringe Area. Toshikeikaku Supplement, 21, 427-432. (J-E)

Yokoya, K., K. Mitsuyoshi, S. Hagishima and N. Kin (1984): A Study on the Effects that Zoning Allocation has in Relationship to Newly Constructed Building: a Case Study of Fukuoka City. Toshikeikaku Supplement, 19, 427-432. (J-E)

Note: The term "symposium paper" refers to a paper presented at the IGU International Symposium on Land Use Change and Its Processes. The proceedings are due to be published in English in an IGU publication in the spring of 1988 .

\title{
本邦における土地利用研究の現況と課題
}

\author{
氷見山幸夫*·実 清隆 ${ }^{* *}$
}

\begin{abstract}
土地利用は地理学の重要なテーマの一つであり, 研究 の歴史も古い。しかし，本邦の地理学界においては，そ れは都市地理学や農村地理学等に付随して扱われること が多く，土地利用学としての発展は遅れていた。また土
\end{abstract} 地利用が他分野で扱われる機会が増え，拡散しまとまり を欠く事態となり，関連研究の集約・整理と，より良い 国土利用を目指しての研究の方向づけと振興が求められ ていた。そうした背景の下で，1985年10月に日本地理学
会に土地利用研究グループが設置され, 更に1987年 8 月 には国際地理学連合主催・日本地理学会後援の土地利用 国際会議が旭川・札幌で開催され, 多大の成果をあげた。 本稿はこれらの成果を基に, 本邦における1980年代の土 地利用研究を概観し, 各研究課題の位置付けと問題点を 明らかにし, 今後の研究のあるべき方向を提示するもの である。

* 北海道旭川市北門町 9 丁目 北海道教育大学旭川分校

** 富山県富山市五福 3190 富山大学教育学部 